ISSN 2073-4441

www.mdpi.com/journal/water

Article

\title{
Water Recycling in Australia
}

\section{Nick Apostolidis *, Chris Hertle and Ross Young}

GHD, 201 Charlotte Street, Brisbane Queensland 4000 Australia;

E-Mails: chris.hertle@ghd.com (C.H.); ross.young@ghd.com (R.Y.)

* Author to whom correspondence should be addressed; E-Mail: napostolidis@ghd.com; Tel.: +61-7-3316-3603; Fax: +61-7-3316-3040.

Received: 3 August 2011; in revised form: 25 August 2011 / Accepted: 31 August 2011 /

Published: 9 September 2011

\begin{abstract}
Australia is the driest inhabited continent on earth and, more importantly, experiences the most variable rainfall of all the continents on our planet. The vast majority of Australians live in large cities on the coast. Because wastewater treatments plants were all located near the coast, it was thought that large scale recycling would be problematic given the cost of infrastructure and pumping required to establish recycled water schemes. This all changed when Australia experienced a decade of record low rainfall and water utilities were given aggressive targets to increase the volume of water recycled. This resulted in recycled water being accepted as a legitimate source of water for non-drinking purposes in a diversified portfolio of water sources to mitigate climate risk. To ensure community support for recycled water, Australia lead the world in developing national guidelines for the various uses of recycled water to ensure the protection of public health and the environment. Australia now provides a great case study of the developments in maximizing water recycling opportunities from policy, regulatory and technological perspectives. This paper explores the evolution in thinking and how approaches to wastewater reuse has changed over the past 40 years from an effluent disposal issue to one of recognizing wastewater as a legitimate and valuable resource. Despite recycled water being a popular choice and being broadly embraced, the concept of indirect potable reuse schemes have lacked community and political support across Australia to date.
\end{abstract}

Keywords: water recycling; water cycle management; history of reuse in Australia; indirect potable reuse; advanced water treatment; national recycled water guidelines 


\section{Introduction}

It is not surprising that Australia is a good case study for water recycling. Recognized as one of the driest continents on earth with one of the most variable climates, Australia offers some valuable lessons to other countries looking at developing their wastewater management practices so as to maximize the benefits from this increasingly valuable source of water.

A series of seminal papers [1-3] on water reuse some 40 years ago suggested that Australia needed to view wastewater as a resource rather than a waste. These papers generally concluded that, to achieve an increase in the use of recycled water, the following would be required:

- introduction of community and stakeholder programs to increase awareness on the benefits of recycled water;

- an increase in drinking water prices to enable recycled water to compete, rather than holding prices at artificially low levels;

- research programs covering the public health, environmental and social aspects of recycled water to build and engender community confidence.

Four decades later, despite significant technological developments, the creation and adoption of national water recycling guidelines and a dramatic increase in the number of recycled water schemes many of the above conclusions are still valid today not only for Australia but for most parts of the world.

Over this 40-year period some key factors have changed dramatically, namely:

- the population of Australia increased by 50\% mostly in the major urban areas situated on the coast;

- the most severe drought in living history;

- significant changes in community's awareness and attitude towards water recycling [4]. Surveys of Australians over the last decade have consistently shown that there is very strong community support for increasing the use of recycled water for myriad non-drinking purposes.

The following paper explores the drivers for change and provides a range of case studies that illustrate the policies and technologies that have been implemented in Australia over the past 40 years.

The paper also looks at future challenges and opportunities for water recycling.

\section{Historical Perspective}

In the 1970s, most wastewater management practices were based on effluent disposal to receiving waters including inland waterways and the ocean. A few landmark projects include Melbourne's Western Treatment Plant, one of the world's largest lagoon-based treatment plants where the effluent was used to irrigate pasture for grazing animals. Most other major cities on the coast had ocean outfalls at various distances from the shore. This was and probably still is the norm for most coastal cities across the globe.

The key driver to improve wastewater management in the 70 s and 80 s was the deleterious impact of wastewater discharges on water quality of the receiving waters and associated risks to public health. This was particularly the case in popular coastal locations that were experiencing significant population growth and where swimming and surfing were popular recreational pursuits. 
Perhaps a step change occurred in the approach to wastewater management following the community's outcry in Sydney about disposal of wastewater close to their world famous beaches. The irony is that this occurred at the time when Sydney was just about to commission its deeper ocean outfalls that took the discharge points much further out to sea thus minimizing impacts on the beaches.

The issue became a mainstream media topic and virtually every water utility or industry that discharged treated wastewater to the sea or a sensitive water body was challenged by its local community to move to a new paradigm that embraced the concept of recycling. The heightened community awareness combined with a greater focus on protecting the ecological and natural landscape values of the waterways forced many authorities to reconsider their current practices and look to alternative modes of wastewater management [5].

Following community and media pressure, a significant number of effluent re-use schemes emerged primarily aimed at reducing discharges to waterways. This mainly involved the use of treated effluent on land for irrigation of recreation grounds, landscaping. Moreover, in regional centres treated effluent was widely used for agricultural and horticultural crops and some industrial applications. Virtually every wastewater treatment plant augmentation or upgrade had to demonstrate that they considered alternative uses to waterway discharges to gain community approval for the project [6]. This trend led to the establishment of the Australian National Water Quality Management Strategy guidelines [7]. These guidelines were adopted by all states and territories in Australia [8,9] and they were embedded in the states and territories' respective environmental legislation. The guidelines embraced the $3 \mathrm{R}$ principle that basically said that before you can discharge to any waterway you must demonstrate that you have taken all steps to reduce, reuse or recycle the wastewater before environmental approval would be granted [10]. The guidelines also required that the community be engaged in the planning process to ensure there was broad community and stakeholder support for new or upgraded water recycling schemes.

The severe algal bloom events that were experienced in the 1990s focused attention on the impacts from nutrients in wastewater discharges. This resulted in the introduction of nutrient limits and the upgrading of most of the country's major wastewater treatment plants discharging into waterways. The additional cost of upgrading for nutrient reduction resulted in a further increase in the number of re-use schemes [11]. For example, Hervey Bay, a 40,000 person city in coastal Queensland discharged into the local waterways. A decision was made to develop a re-use scheme that used all the treated effluent to irrigate, pastures, tree farms and local sugar cane farms instead of upgrading the treatment plant for nutrient reduction.

Some innovative state governments provided subsidies to communities to encourage reuse. During this period a great variety of re-use schemes emerged ranging from industrial cooling towers, golf course irrigation, major agriculture irrigation schemes, to domestic dual water supply schemes including several proposals for indirect potable re-use.

The Sydney Olympics in 2000, with the theme "green games", provided a great opportunity to showcase what can be done in an urban environment to reduce the water footprint. The Olympic Village was developed to show case how urban water cycle management principles could be adopted in new urban developments in an integrated manner comprising the water supply, wastewater and stormwater systems. The Olympic Village showed that it was possible to achieve significant reductions in the amount of water imported from the environment through more recycling without loss of amenity 
or functionality. Moreover, it showed that, if integrated water management principles are incorporated in the planning process at the outset, it can be delivered at a similar cost to traditional schemes.

The onset of the great millennium drought in Australia brought a greater focus on the value of recycled water. Rather than looking at wastewater as waste, under pressure from communities, water utilities started to look at it as a valuable source of water. The change in attitude was assisted by the Council of Australian Governments (CoAG) [12] supporting an intergovernmental agreement on the national water initiative and, specifically, clause 90 in which the parties agreed that the outcome for urban water reform is to "(iii) encourage the reuse and recycling of wastewater where cost effective." It was at this time that state governments across Australia began to set recycled water targets for the urban water utilities. These targets played a significant role in focusing attention on opportunities to develop recycled water schemes that previously may not have been considered.

Most of the Australian population choose to live in large cities close to the coast. Because wastewater systems were designed to take advantage of gravity, wastewater plants were generally located close to the coast to allow for easy discharge of treated effluent to ocean and bay receiving environments. This meant that at the location where recycled water was produced was a long way from areas where recycled water could be used in meaningful quantities. Despite the cost of constructing recycled water pipe networks and the cost of pumping recycled water, the number of recycled water schemes increased dramatically. The growth of recycled water increased in response to the drought but also because the community expressed strong support for the greater use of recycled water. Consequently, the volume of recycled water produced by the urban water industry increased from 76 gigaliters in 2000 to 180 gigaliters in 2010 [13].

As outlined previously, attitudes towards water recycling have changed significantly over the past 40 years. Early attempts for higher valued re-use, as an alternative to ocean discharge, were met by community fear and regulatory conservatism [11]. Lack of awareness and the absence of a sense of urgency for change dominated the thinking until the late 1990s. Many practitioners frustrated by this attitude commenced community education programs and promoted a range of demonstration projects to help raise awareness and overcome public fear of re-cycled water. The onset of the great millennium drought created a sense of urgency and brought greater focus to the opportunities from recycled water. The community started to appreciate the value of water and were prepared to consider a wider range of uses. Community surveys consistently showed that there was an overwhelming support of most non-potable uses however there was and probably still is a significant minority concerned with applications that involve potable use [14]. The Toowoomba plebiscite on indirect potable re-use showed that even during an emergency, unless there is bi-partisan support for such schemes, it is very easy to create fear amongst the community to block potable re-use applications despite all the good science that proves it is safe to do so.

In 2009 the Australian government funded the development of national water recycling guidelines as a means of facilitating the greater use of recycled water in a manner that would minimize public health risks and engender the greater use of recycled water for a wide range of uses. The Environment Protection and Heritage Council, the Natural Resource Management Ministerial Council and the National Health and Medical Research Council developed guidelines in consultation with industry for the safe use of recycled water over a two year period. 
The guidelines [15] include:

- Australian Guidelines for Water Recycling: Managing Health and Environmental Risks;

- Australian Guidelines for Water Recycling: Managing Health and Environmental Risks (Phase 2): Augmentation of Drinking Water Supplies;

- Australian Guidelines for Water Recycling: Managing Health and Environmental Risks (Phase 2): Stormwater Harvesting and Reuse;

- Australian Guidelines for Water Recycling: Managing Health and Environmental Risks (Phase 2): Managed Aquifer Recharge.

These recycled guidelines are valuable references for other countries wishing to encourage recycled water schemes whilst addressing risk factors.

\section{The Current Situation}

With most of the eastern states of Australia now out of drought, the sense of urgency has dissipated. Despite this, the community has embraced water conservation and most of the non-potable recycling initiatives. Water recycling has become main-stream for most new developments or the re-development of existing urban areas.

Most agencies now have updated their regulations to allow the use of decentralized solutions such as grey water recycling and rainwater tanks in urban areas. Past barriers to non-potable applications in urban areas such as use of recycled water for firefighting, toilet flushing and cooling towers have been largely removed.

The Commonwealth government has established the Australian Water Recycling Centre of Excellence [16] to undertake research and development into water recycling to broaden the use of recycled water and overcome some of the technological hurdles that currently exist. Due to the substantial rainfall that eastern Australia experienced in the spring of 2010 and the summer of 2011, the pressure to develop further indirect (and direct) potable re-use has eased. However, if there is one lesson that Australians have learnt over the last decade, it is that the climate shifts in Australia have been rapid and spectacular and recycled water schemes are now recognized as being a vital component of a diverse portfolio of water supply sources to reduce climate risks.

The concept of cities of the future where water is an essential element in making our cities more sustainable and livable ensures that recycled water will continue to be a valuable source of water into the future.

\section{Case Studies}

The following table (Table 1) provides a snapshot of some water recycling schemes comprising a range of applications that can be found in Australia. The table gives a brief description of each scheme including its size, proportion of wastewater that is recycled and how much of the treated product is used to substitute water that would have otherwise would have been sourced from the potable water supply system. 
Table 1. Australian Water Recycling Schemes.

\begin{tabular}{|c|c|c|c|c|}
\hline $\begin{array}{l}\text { Scheme } \\
\text { Location } \\
\text { Year Implemented }\end{array}$ & $\begin{array}{l}\text { Capacity } \\
\text { ML Per } \\
\text { Annum }\end{array}$ & $\begin{array}{c}\% \text { of } \\
\text { waste } \\
\text { water } \\
\text { recycled }\end{array}$ & $\begin{array}{c}\text { \% potable } \\
\text { water } \\
\text { substi- } \\
\text { tution }\end{array}$ & Description \\
\hline
\end{tabular}

REGIONAL SCHEMES

\begin{tabular}{|c|c|c|c|c|}
\hline $\begin{array}{l}\text { Western Corridor } \\
\text { Recycled Water Project } \\
\text { Brisbane, QLD } \\
2009\end{array}$ & $\begin{array}{l}65,000 \\
(110,000 \\
\text { Ultimate) }\end{array}$ & $75 \%$ & $100 \%$ & $\begin{array}{l}\text { This is one the largest water recycling projects in the world. The } \\
\text { scheme collects effluent from three advanced water treatment plants, } \\
\text { namely Bundamba, Luggage Point and Gibson Island. Wastewater is } \\
\text { treated by these plants in Brisbane incorporating micro-filtration, } \\
\text { reverse osmosis, advanced oxidation and residual disinfection. }\end{array}$ \\
\hline
\end{tabular}

The initial installed treatment capacity is $182 \mathrm{~mL} / \mathrm{d}$ with provision for expansion to $310 \mathrm{~mL} / \mathrm{d}$. The project also includes approximately 190 $\mathrm{km}$ of large-diameter pipelines and various pump stations.

The recycled water is used to supply water to power stations, industrial applications and the remaining directed to the main drinking water supply storage. The Western Corridor scheme will only be used for indirect potable reuse when the combined water storages are below 40 percent.

The scheme incorporates a seven barrier process as depicted in the schematic below before recycled water is returned to the household for drinking purposes.

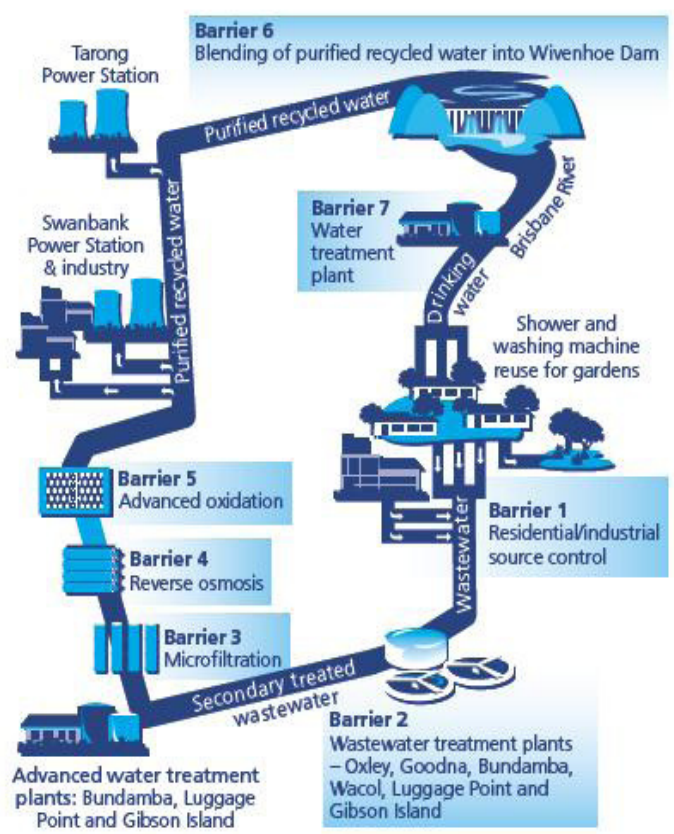

The recent floods have filled all the water supply storages so the recycling scheme is now not operating at full capacity.

The recycling scheme, combined with the water grid and desalination facility on the Gold Coast has made the Brisbane region far more resilient to climate change and will be able to accommodate the growth of the region that is expected to double the next 40 years. 
Table 1. Cont.

\begin{tabular}{|c|c|c|c|c|}
\hline $\begin{array}{l}\text { Scheme } \\
\text { Location } \\
\text { Year Implemented }\end{array}$ & $\begin{array}{l}\text { Capacity } \\
\text { ML Per } \\
\text { Annum }\end{array}$ & $\begin{array}{c}\% \text { of } \\
\text { waste } \\
\text { water } \\
\text { recycled }\end{array}$ & $\begin{array}{c}\text { \% potable } \\
\text { water } \\
\text { substi- } \\
\text { tution }\end{array}$ & Description \\
\hline
\end{tabular}

REGIONAL SCHEMES

Eastern Treatment Plant

(ETP) Water Recycling

Scheme

Melbourne, VIC

$209 / 10$

2012
$20 \%$

$1 \%$

$30 \%$

$\begin{array}{lll}(120,000 & 50 \% & 30 \% \\ \text { Ultimate }) & \end{array}$

The Eastern Treatment Plant is Melbourne's second biggest facility serving over 1.5 million persons. Secondary treated effluent from this plant is recycled both on and off site with excess treated effluent discharged via a $56 \mathrm{~km}$ pipeline to Bass Strait. On average it treats $330 \mathrm{~mL} / \mathrm{d}$

A tertiary filtration plant is now being implemented to reduce marine impacts at the outfall and to increase opportunities to use the recycled water for higher valued uses such "third pipe" residential development, irrigation of recreation facilities (e.g., golf courses, playing fields, etc) and supply to agricultural customers.

The new advanced tertiary treatment plant will have a peak capacity of $750 \mathrm{~mL} / \mathrm{d}$ and will be capable of expanding to treat all the treated wastewater produced by the ETP. This will greatly increase the opportunities for higher value recycled water use.

The treatment plant is due for completion by the end of 2012 and will use ozone, biological media filtration followed by ultraviolet and chlorine disinfection.

\section{NEW URBAN DEVELOPMENTS}

\section{Rouse Hill}

Sydney, NSW

1995
3,200

$(15,000$

ultimate)
Australia's first dual water supply scheme and one of the largest residential recycling schemes in the world. Begun in 1995, it now supplies some 19,000 homes recycled water for toilet flushing, watering gardens, washing cars and other outdoor purposes. Ultimately the scheme will serve up to 36,000 .

The scheme, supplies recycled water via a third "purple" pipe system to ensure the drinking water supply and the recycled supplies are separated. Recycled water in this system is treated to a very high standard, with all microbial contaminants and the vast

majority of chemical contaminants removed. The recycled water is not designed for drinking, but accidental drinking for a short time will not cause harm.

Sydney Olympic Park Authority/Newington — integrated sewage treatment and stormwater collection undergoe advanced tertiary treatment, with water returned for non-potable purposes (e.g., irrigation of parklands and playing fields). A dual reticulation system was also implemented in the adjacent suburb of Newington that was used by the 2000 Olympic athletes for accommodation.

This project was developed to demonstrate the potential in residential recycling to the residential development industry and the world community in general.

\begin{tabular}{|c|c|c|c|c|}
\hline $\begin{array}{l}\text { Aurora, } \\
\text { Epping North, VIC }\end{array}$ & 1,100 & $90 \%$ & $100 \%$ & $\begin{array}{l}\text { The Aurora development at Epping North incorporates a "third pipe" } \\
\text { system for non-potable use at 9,000 dwellings. Recycled water is } \\
\text { provided from a dedicated Class A membrane plant followed by } \\
\text { ultraviolet and chlorine disinfection }\end{array}$ \\
\hline
\end{tabular}

2005

This scheme has been developed by Yarra Valley Water and is located in a rapidly growing area. The recycled water volumes are predicted to grow in the future.

Mawson Lakes is a new suburb in Adelaide's north-will be home to about 10,000 people. The scheme uses a combination of treated effluent produced from a DAFF plant at Bolivar and harvested stormwater to complement the normal mains water supply via a second purple pipe.

Adelaide $S A$

Eventually, it will save about $800 \mathrm{~mL}$ of mains water that otherwise would have being drawn from the Murray River or the new desalination plant. The Bolivar treatment plant also supplies the Northern Adelaide Plains (Virginia) horticultural area with recycled water. 
Table 1. Cont.

\begin{tabular}{|c|c|c|c|c|}
\hline $\begin{array}{l}\text { Scheme } \\
\text { Location } \\
\text { Year Implemented }\end{array}$ & $\begin{array}{l}\text { Capacity } \\
\text { ML Per } \\
\text { Annum }\end{array}$ & $\begin{array}{c}\% \text { of } \\
\text { waste } \\
\text { water } \\
\text { recycled }\end{array}$ & $\begin{array}{c}\text { \% potable } \\
\text { water } \\
\text { substi- } \\
\text { tution }\end{array}$ & Description \\
\hline
\end{tabular}

\section{NEW URBAN DEVELOPMENTS}

\begin{tabular}{llll}
\hline Pimpama Coomera & 5,000 & $100 \%$ & $80 \%$ \\
Gold Coast, $Q L D$ & $(10,000$ & & \\
& Ultimate $)$ & &
\end{tabular}

Caboolture Water

Reclamation Scheme

3,500

Caboolture, $Q L D$
This is major integrated water management scheme that includes a dual supply system for recycled water for non-potable applications such as garden watering, toilet flushing and firefighting. Each house is also equipped with rainwater tanks to further supplement non potable applications.

All wastewater is collected and treated at a regional treatment and water recycling facility. Excess recycled water is used to supply water to municipal recreation fields and nearby sugar cane farms.

The Pimpama Coomera region on the Gold Coast is one of South East Queensland's fastest growth areas. By 2050 the region is expected to house 150,000 people.

Commenced in 2003, the Pimpama Coomera

Waterfuture Project incorporates a full water cycle approach, making use of water sensitive urban development in streetscapes, recycled water via third pipes to houses for garden watering and toilet flushing, rainwater tanks and water-efficient fixtures in housing developments.

The scheme is expected to reduce demand on drinking water supply systems to these households by 70 percent as well as improve the quality of urban runoff.

A schematic of the system is shown below:

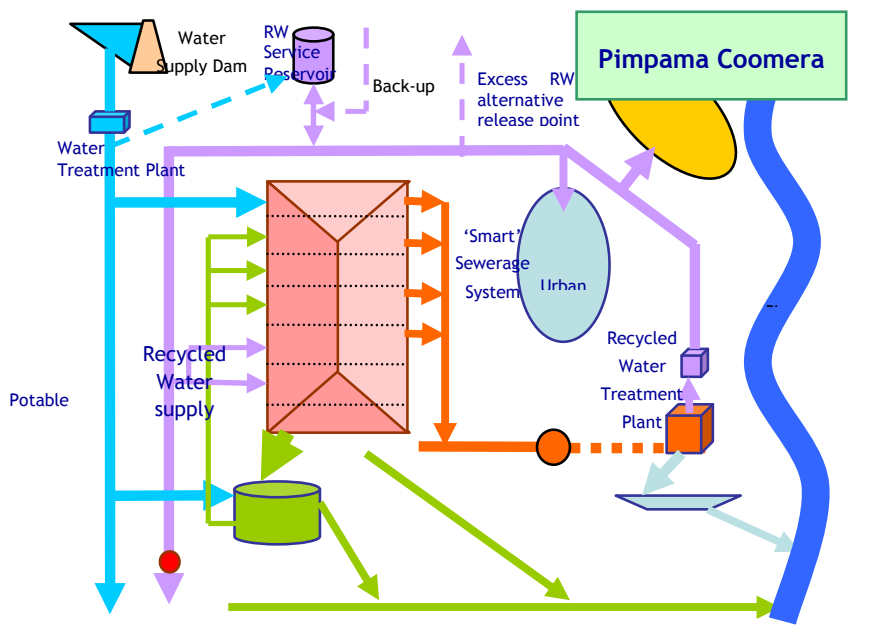
tertiary treatment plant-MBBR (anoxic with methanol dosing), pre-ozonation, flash mix coagulation, DAFF, ozonation, BAC, ozonation.

The plant was originally designed to permit indirect potable re-use by returning the discharge upstream of the main river intake to the city's drinking water supply. However, due to public opposition, the recycled water is only used for non-potable applications and the majority disposed to Caboolture River downstream of the river intake. Plans are in progress to use the recycled water for non-potable applications for industry and irrigation of landscapes and recreational grounds. 
Table 1. Cont.

\begin{tabular}{|c|c|c|c|c|}
\hline $\begin{array}{l}\text { Scheme } \\
\text { Location } \\
\text { Year Implemented }\end{array}$ & $\begin{array}{l}\text { Capacity } \\
\text { ML Per } \\
\text { Annum }\end{array}$ & $\begin{array}{c}\% \text { of } \\
\text { waste } \\
\text { water } \\
\text { recycled }\end{array}$ & $\begin{array}{c}\text { \% potable } \\
\text { water } \\
\text { substi- } \\
\text { tution }\end{array}$ & Description \\
\hline
\end{tabular}

\section{AGRICULTURE IRRIGATION}

\section{Western Treatment}

Scheme

Melbourne, Vic

1897-1930
$50 \%$

$0 \%$
$1930-1986$

1936-2004

2004-2011
The Western Treatment plant is one of the world's largest lagoon based water treatment plants in the world. Commissioned in the 1890s the plant used three sewage treatment methods: land filtration, grass filtration and lagoon treatment.

The land filtration method dates back to 1897, and was the main sewage treatment method used during summer. In this method, an open paddock was flooded with sewage, up to a depth of $10 \mathrm{~cm}$.

The treatment process normally took about three weeks. It took about one to two days to flood the paddocks, and a further five days for the paddocks to dry out and for sewage to seep through the soil. Then, sheep and cattle grazed on the paddocks for about two weeks, before the land was flooded with sewage again.

The grass filtration method was adopted in the 1930s as the main winter treatment method. There were two stages in this process pre-treatment and filtration in grass paddocks.

The first treatment lagoon was constructed in 1936. Lagoon treatment facilities have been continuously upgraded to meet the needs of Melbourne's growing population. The first large, modern lagoon was installed in 1986.

Today all sewage at the Western Treatment Plant is treated in modern lagoons, replacing old lagoons and traditional land and grass filtration methods. The new methods remove large amounts of nitrogen, which would otherwise enter the bay, and generate high quality recycled water, which is a valuable resource for onsite and offsite use.

Following the major upgrade of the Plant in 2004, large tracts of farming land and dozens of old ponds are no longer needed for sewage treatment, opening up opportunities for alternative farming operations using recycled water.

$37,000 \mathrm{~mL}$ of treated water from lagoons was used to irrigate pasture in the $09 / 10$ year and $17,199 \mathrm{~mL}$ was used for on-site habitat conservation.

\begin{tabular}{llll}
\hline Lower Molonglo Scheme & 50,000 & $100 \%$ & $5 \%$
\end{tabular}

Canberra, ACT

1985

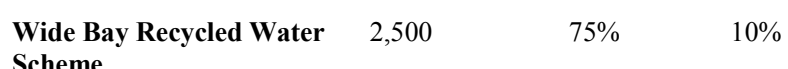

Wide Bay, QLD

1995
The Lower Molonglo Water Quality Control Centre provides tertiary treated water to surrounding golf courses and vineyards. Any remaining water is discharged to the Molonglo River, which then flows to the Murrumbidgee River and Burrinjuck Dam. So effectively this provides for $100 \%$ water re-use primarily for agricultural purposes. 
Table 1. Cont.

\begin{tabular}{|c|c|c|c|c|}
\hline $\begin{array}{l}\text { Scheme } \\
\text { Location } \\
\text { Year Implemented }\end{array}$ & $\begin{array}{l}\text { Capacity } \\
\text { ML Per } \\
\text { Annum }\end{array}$ & $\begin{array}{c}\% \text { of } \\
\text { waste } \\
\text { water } \\
\text { recycled }\end{array}$ & $\begin{array}{c}\text { \% potable } \\
\text { water } \\
\text { substi- } \\
\text { tution }\end{array}$ & Description \\
\hline
\end{tabular}

\section{AGRICULTURE IRRIGATION}

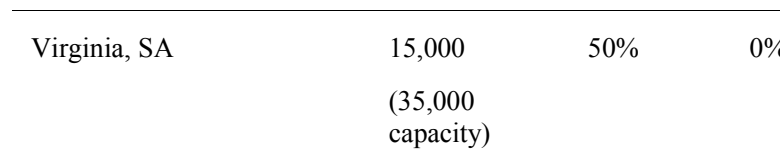

Operating since 1999, the Virginia Recycling Scheme
north of Adelaide transfers recycled water to more than 200 market
gardeners for production of vegetables and other edible produce.

The effluent from the Bolivar STP is treated utilizing a DAFF process and disinfection to produce Class A water suitable for use on horticultural farms.

The scheme is a co-operative undertaking of a number of entities and is managed by Water Reticulation Services Virginia.

The implementation of the scheme required a $\$ 30$ million upgrade to

SA Water's Bolivar wastewater treatment plant to produce recycled water suitable for irrigating food crops. With financial assistance from SA Water and the Federal Government, an additional \$22 million recycled water distribution network was constructed.

Use of reclaimed water is expected to increase as the horticultural industry continues to expand production, as groundwater substitution takes place, and as growers establish on-site infrastructure and refine irrigation methods.

It is expected that 50 percent to 70 percent of the treated wastewater from the Bolivar plant could be used for irrigation on the northern Adelaide Plains.

\section{INDUSTRIAL RECYCLING}

\begin{tabular}{|c|c|c|c|c|}
\hline $\begin{array}{l}\text { Luggage Point Industrial } \\
\text { Reuse Scheme } \\
\text { Brisbane, } Q L D \\
2000\end{array}$ & 3,600 & $10 \%$ & $100 \%$ & $\begin{array}{l}\text { This recycling plant is different to the Luggage Point plant in the } \\
\text { Western Corridor scheme. This } 18 \text { million plant was commissioned in } \\
\text { October } 2000 \text {. It provides } 10 \mathrm{~mL} / \mathrm{d} \text { of tertiary treated (fine screening, } \\
\text { MF, RO and conditioning) water to the nearby BP Refinery for boiler } \\
\text { feedwater and emergency fire-fighting supply. }\end{array}$ \\
\hline $\begin{array}{l}\text { Kwinana Industrial } \\
\text { Recycling Plant }\end{array}$ & 6,000 & $10 \%$ & $100 \%$ & $\begin{array}{l}\text { The Kwinana industrial recycling scheme developed by the Water } \\
\text { Corporation is capable of delivering about } 6 \mathrm{GL} / \text { year to heavy industries } \\
\text { in the Kwinana industrial area, south of Perth. }\end{array}$ \\
\hline
\end{tabular}

Kwinana, Perth, WA

2004

This scheme takes treated wastewater from the

Woodman Point wastewater treatment plant and further treats it using microfiltration and reverse osmosis membranes. This produces high quality recycled water with low salinity that can be used in various industrial processes.

The use of this recycled water replaces drinking water formerly used by these industries in their processes

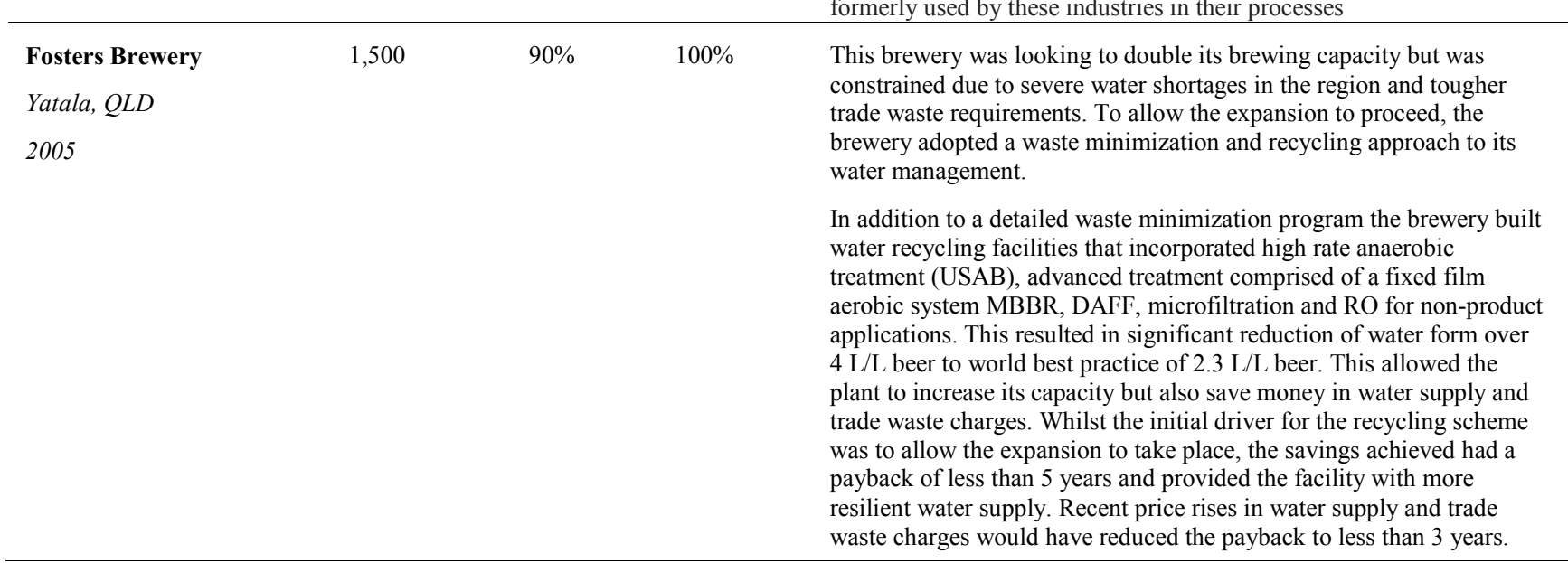


Table 1. Cont.

\begin{tabular}{lcccc}
\hline Scheme & Capacity & $\begin{array}{c}\text { \% of } \\
\text { waste }\end{array}$ & $\begin{array}{c}\text { \% potable } \\
\text { water }\end{array}$ & Description \\
Location & ML Per & $\begin{array}{c}\text { water } \\
\text { recycled }\end{array}$ & $\begin{array}{c}\text { substi- } \\
\text { tution }\end{array}$ & \\
Year Implemented & & Annum & & \\
\hline
\end{tabular}

INDUSTRIAL RECYCLING

\begin{tabular}{|c|c|c|}
\hline $\begin{array}{l}\text { Lion Nathan National } \\
\text { Foods, XXXX Brewery }\end{array}$ & 1,500 & $90 \%$ \\
\hline
\end{tabular}

Foods, $X X X X$ Brewery

Brisbane, $Q L D$

2010

\begin{abstract}
The recycling plant implemented in this brewery reduced water consumption from $3.8-\mathrm{L} / \mathrm{L}$ beer to $2.0-\mathrm{L} / \mathrm{L}$ beer. The brewery wastewater passes through a treatment scheme of physical, biological and chemical steps using high rate anaerobic reactor (Circox), DAF, DAFF, microfiltration, RO, UV and Chlorine dioxide. Over $70 \%$ is re-used for non-product applications onsite. Recycle of the high quality water has also led to a reduction in chemicals required for cleaning, cooling towers and boiler water treatment. A significant amount of soluble organics in the wastewater are converted into biogas using a high rate anaerobic treatment process. The produced biogas contains $\sim 75 \%$ methane and is co-fired in the gas fired boilers as an alternative to natural gas. This approach provides a reduction in costs and in the environmental footprint associated with managing the water and waste from the brewery. The capital and operating costs savings (including a government grant) achieved a payback of 4 years.
\end{abstract}

\begin{tabular}{|c|c|c|c|c|}
\hline $\begin{array}{l}\text { Illawara Recycled Water } \\
\text { Scheme Stage } 1\end{array}$ & 7,300 & $40 \%$ & $100 \%$ & $\begin{array}{l}\text { Illawarra Wastewater Strategy-provides } 20 \mathrm{~mL} / \mathrm{d} \text { of recycled water by } \\
\text { an MF/RO process on secondary effluent. The recycled water is mainly } \\
\text { used by BlueScope steel in place of potable water for } \\
\text { non-potable water applications. }\end{array}$ \\
\hline
\end{tabular}

Illawarra, NSW The treatment process adds membrane filtration and

2006 reverse osmosis technology to the Wollongong wastewater treatment plant to deliver recycled water for purposes such as around-the-clock steel making, cooling and dust suppression. The scheme's viability is due to the proximity of the recycled water plant and the high demand from this particular industry.

The scheme alone will reduce the use of drinking water across the total Illawarra region by 17 percent

\begin{tabular}{|c|c|c|c|c|}
\hline $\begin{array}{l}\text { Wollongong Recycled } \\
\text { Water Scheme Stage } 2\end{array}$ & 460 & $2.5 \%$ & $100 \%$ & $\begin{array}{l}\text { The above scheme was further expanded to supply water to the Port } \\
\text { Kembla Coal Terminal resulting in further reducing the demand on the } \\
\text { drinking water supply. }\end{array}$ \\
\hline
\end{tabular}

2010

\begin{tabular}{|c|c|c|c|}
\hline $\begin{array}{l}\text { St Mary's Replacement } \\
\text { Flows Scheme }\end{array}$ & 18,000 & $100 \%$ & $\begin{array}{l}\text { A recycled water plant at St Marys and a distribution pipeline will } \\
\text { replace } 18 \mathrm{GL} \text { of water that would have been released from dams for } \\
\text { environmental flow purposes. }\end{array}$ \\
\hline 2010 & & & $\begin{array}{l}\text { This a regional recycling plant that receives treated effluent from three } \\
\text { inland wastewater treatment plants and is further purified using } \\
\text { ultrafiltration and reverse osmosis technology. The highly treated } \\
\text { recycled water, which is similar in quality to drinking water, is then } \\
\text { pumped to Penrith. It is released into the Hawkesbury-Nepean River } \\
\text { below Penrith Weir. }\end{array}$ \\
\hline
\end{tabular}

(Radcliffe, 2004) [6], (Hopkins and Barr, 2002) [10], (WSAA 2006) [17].

\title{
5. The Future
}

The pressures from population growth, urbanization and climate change will continue and thus the demand for water recycling will increase in future. From the above case studies we will have excellent operational data to design new systems that protect the environment, reduce the carbon footprint of the water industry are acceptable to our communities. 
In future urban water recycling schemes will be:

- more energy efficient so that they do not contribute to the GHG emissions;

- better integrated with urban planning;

- more effective in substituting water imported to cities at either the regional or household level.

Industries will manage their water more efficiently within their premises and some may be co-located allowing for multiple uses of water before any release to the environment

There will be an increasing trend to recovering other high-value by-products from wastewater such as Phosphorus, Nitrogen, Potassium and other commodity chemicals. The term wastewater treatment plans may change to water management and nutrient and energy recovery plants.

\section{References}

1. Gutteridge, Haskins and Davey. Planning for the Use of Sewage; Report for the Department of Environment Housing and Community Development Canberra; Australian Government Publishing Service: Canberra, Australia, 1976.

2. Gutteridge, Haskins and Davey. Strategies towards the Use of Reclaimed Water in Australia; Report for Reclaimed Water Committee; Ministry of Water Resources and Water Supply: Melbourne, Australia, 1977.

3. Gutteridge, Davey and Haskins. Planning for the Use of Reclaimed Water in Victoria; Report for the Reclaimed Water Committee; Ministry of Water Resources and Water Supply: Melbourne, Australia, 1978.

4. Cadee, K. Security through Diversity-The Water Crisis: Fact or Fiction?; Water Corporation: Perth, Australia, 2006.

5. Foley, J.; Batstone, D.; Keller, J. Water Recycling in Australia-Position Paper; Advanced Water Management Centre: Brisbane, Australia, 2006.

6. Radcliffe, J.C. Water Recycling in Australia; Australian Academy of Technological Sciences and Engineering: Melbourne, Australia, 2004.

7. Department of Sustainability, Environment, Water, Population and Communities. Australian National Water Quality Management Guidelines; Canberra, Australia, 1992; Available online: http://www.environment.gov.au/water/policy-programs/nwqms/index.html (accessed on 15 August 2011).

8. DHS. South Australian Reclaimed Water Guidelines-Treated Effluent; Department of Human Services: Adelaide, Australia, 1999.

9. Queensland Water Recycling Guidelines; Environmental Protection Agency: Brisbane, Australia, 2005.

10. Hopkins, L.; Barr, K. Operating a Water Reclamation Plant to Convert Sewage Effluent to High Quality Water for Industrial Reuse. In Proceedings of the IWA 3rd World Water Congress, Melbourne, Australia, 7-12 April 2002.

11. Solley, D.; Boerlage, S.; Traves, W. Climate Resilient Water Supply in South East Queensland, Australia. Proceedings of Western Canada Water Conference, Calgary, Alberta, Canada, Sept 21-24, 2010. 
12. Department of Sustainability, Environment, Water, Population and Communities. Intergovernmental Agreement on the National Water Initiative; Canberra, Australia, 2004.

13. Water Services Association of Australia. WSAA Report Card 2009-2010, Performance of the Urban Water Industry and Projections for the Future; Melbourne, Australia, 2010.

14. Queensland Water Commission. Water for Today, Water for Tomorrow-South East Queensland Regional Demand Management Program 2007-2009; Brisbane, Australia, 2008.

15. Environment Protection and Heritage Council, The National Health and Medical Research Council, and the Natural Resources Management Ministerial Council. Australian Guidelines for Water Recycling; Canberra, Australia, 2009.

16. Australian Water Recycling Centre of Excellence; Available online: http://www.australianwaterrecycling.com.au (accessed on 16 August 2011).

17. Refilling the Glass-Exploring the Issues Surrounding Water Recycling in Australia; WSAA Position Paper No. 2; Water Services Association of Australia: Melbourne, Australia, 2006.

(C) 2011 by the authors; licensee MDPI, Basel, Switzerland. This article is an open access article distributed under the terms and conditions of the Creative Commons Attribution license (http://creativecommons.org/licenses/by/3.0/). 